Contents list avaliable at Directory of Open Access Journals (DOAJ)
Aulad : Journal on Early Childhood
Vol 4 No 2 2021, Pages 114-121
ISSN : 2655-4798 (Printed); 2655-433X (Online)
Journal Homepage: https://aulad.org/index.php/aulad

\title{
Upaya Meningkatkan Kemampuan Bicara Anak Usia Dini Melalui Media Kartu Huruf
}

\author{
Nurlaela ${ }^{1 \bowtie}$, Naimah $^{1}$, Raden Rachmy Diana ${ }^{1}$ \\ Pendidikan Islam Anak Usia Dini, Universitas Islam Negeri Sunan Kalijaga Yogyakarta, Indonesia(1) \\ DOI: 10.31004/aulad.v4i2.114 \\ Corresponding author: \\ [19204030051@student.uin-suka.ac.id]
}

\begin{abstract}
Article Info
Abstrak

Kata kunci:

kemampuan bicara;

media;

kartu huruf

Penelitian ini bertujuan untuk mengetahui peningkatan kemampuan biacara melalui Media Kartu Huruf pada Kelompok B RA Baiturrahman. Jenis metode yang digunakan untuk pengamatan ini menggunkan metode jenis PTK model Kemmis dan McTaggart. Sedangkan dalam pengamatan ini untuk menganlisis data, peneliti menggunakan analisis data kualitatif, yang mana hasil diperoleh dari pengamatan, wawancara, dan dokumentasi. Dalam penelitian ini penelitian melakukan 16 kali dalam pengambilan data. Peningkatan kemampuan berbicara anak kelompok $B$, bahwa pada prasiklus belum ada peningkat dan rata-rata mendapatkan 50\%, kemudian pada siklus 1 mulai mengalami peningkatan presentase komulatif rata-ratanya 70\% dan siklus 2 meningkat hingga 86\%, siklus 3 meningkat hingga 96\%, dan siklus 4 sudah meningkat hingga 99\% ini sudah melebihi kriteria presentase yang diinginkan peneliti. Jadi media kartu huruf merupakan alat bantu guru yang efektif untuk meningkatkan kemampuan berbicara anak usia dini.
\end{abstract}

Keywords:

speaking ability;

media;

letter cards

\begin{abstract}
This study aims to determine the improvement of speaking ability through Letter Card Media in Group B of RA Baiturrahman. The type of method used for this observation uses the Kemmis and McTaggart model of CAR. Meanwhile, in this observation to analyze the data, the researcher used qualitative data analysis, in which the results were obtained from observations, interviews, and documentation. In this study, the research conducted 16 times in data collection. The increase in the speaking ability of the children of group $B$, that in the pre-cycle there was no improvement and the average was getting $50 \%$, then in the first cycle the cumulative percentage increased by an average of $70 \%$ and the second cycle increased to $86 \%$, the third cycle increased to $96 \%$, and cycle 4 has increased to $99 \%$ this has exceeded the percentage criteria desired by the researcher. So the letter card media is an effective teacher's tool to improve early childhood speaking skills.
\end{abstract}

\section{PENDAHULUAN}

Pendidikan anak prasekolah yaitu pendidikan yang memberikan pembinaan-pembinaan dari anak lahir hingga anak usia 6 tahun yang diberikan stimulasi-stimulasi atau rangsangan agar dapat membantu anak siap untuk melanjutkan pendidikan selanjtunya dan jasmani dan rohani anak berkembangan dan tumbuh dengan baik, agar anak tidak merasa kaget ketika mereka melanjuti pendidikan lebih lanjut selain itu anak juga akan terbiasa dengan lingkungan sekolah (Mahendrawani, 2019, p. 89). 
Peningkatan untuk menyadarkan kemampuan anak dalam mengenali potensi pada dirinya serta berkomunikasi dengan lingkungan merupakan perkembangan anak usia dini. Aspek perkembangan ini merupakan aspek perkembangan bahasa. Adapun aspek perkembangan bahasa mencakup kemampuan berbicara, memperhatikan, berkomunikasi, mendengar, membaca dan menulis (Tanjung, 2018, p. 321).

Bahasa adalah salah satu bentuk berkomunikasi yang paling penting untuk mengutarakan sebuah gagasan keinginan serta kebutuhan yang meraka perlukan. Bahasa merupakan sesuatu yang sangat penting untuk mengutarakan pemikiran dan perasaan-perasaan kepada orang lain agar orang lain mengerti pikiran dan apa yang ia rasakan (Fauziddin \& Fikriya, 2020, p. 47). Menurut Sundari dalam jurnalnya bahasa merupakan suatu bentuk atau alat untuk berinteraksi dengan orang lain (Septiyani \& Kurniah, 2017, p. 48). Sedangkan menurut Irene dalam jurnalnya, bahasa yaitu bentuk alat yang terpenting untuk berkomunikasi agar anak dapat mengutarakan keinganan atau pikiran-pikiran dengan orang lain (Irene Fitriana Wahyuni, Prana Dwija Iswara, 2017, p. 1543).

Perkembangan bicara pada anak diperlukan rangsangan sejak dini mungkin dengan baik dan setiap huruf vocal harus jelas dan benar pada saat diajarkan pada anak. Menurut Ratna Istiarini dalam jurnalnya mengutarakan bahwa perkembangan bahasa adalah salah satu potensi penting yang harus dikuasi oleh anak karena akan mempengaruhi bicara, menulis, menyimak, dan membaca (Istiarini, 2014, p. 146).

Berdasarkan penjelasan di atas dapat diringkas bahwa potensi bicara pada anak-anak termasuk aspek perkembangan bahasa. Aspek perkembangan ini sangat diperlukan untuk meningkatkan kempauan bicara anakanak untuk menunjang saat anak memasuki taman kanak-kanak karena disana anak-akan berjumpa dengan teman sebayanya sehingga kemampuan berbicara sangat penting pada saat anak akan berkomunikasi dengan teman maupun guru untuk menyampikan keinginan serta kebutuhan yang anak butuhkan pada saat disekolah.

Keterampilan berbicara yaitu keterampilan berbahasa kedua yang dipelajari oleh seseorang setelah keterampilan menyimak. Made, dkk dalam jurnalnya mengungkapkan bahwa "di Masa anak-anak, anak-anak belajar untuk memperhatikan atau nyimak bahasa, lalu diajarkan untuk belajar bicara, kemudian diajarkan untuk belajar baca dan nulis (Sumantri et al., 2017, p. 1) . Menurut Nurlaelah, dkk dalam jurnalnya persiapan jasmani (fisik) dan rohani (mental) untuk berbicara, merupakan model yang baik untuk ditiru, mempraktekkan, memotivasi, membimbing ini termasuk dalam hal yang sangat penting untuk belajar berbahasa (Nurlaelah, N., \& Sakkir, 2020, p. 114).

Kemampuan bicara pada anak-anak pada masa usia dini sangatlah penting karena dalam kemampuan ini anak mampu mengekspresikan suatu pikiran yang ingin mereka katakana, dalam hal ini jika kemampuan berbicara pada usia 4-5 tahun mengalami keterlambatan anak akan susah untuk berkomunikasi dengan lingkungan sekitarnya, bahkan mereka akan mengalami kesusahan dan mengalami ketidak jelasan dalam menyebutkan huruf a-z (Fitriyani et al., 2019, p. 24).

Media adalah alat untuk membantu guru saat kegaiatan belajar. Saat dilaksanakan kegaiatn belajar anak usia dini diperlukannya bukti ril sehingga media ini sangat diperlukan oleh guru, selain itu media ini akan mempermudah anak dan guru dalam proses pembelajaran. Menurut Darsinah dalam jurnalnya mengatakan bahwa media yaitu sebuah alat untuk membantu untuk menyalurkan informasi agar informasi dapat tersampaikan atau tersalurkan dengan baik (Darsinah, Wusono Indarto, 2014, p. 2). Sedangkan menurut Ratna dalam jurnalnya mengatakan bahwa kartu adalah suatu ide untuk menyanpaian pedapat ataupun konsep dalam bentuk tertulis (Pangastuti \& Hanum, 2017, 55).

Berdasarkan penjelasan diatas, peneliti melakukan studi literatur terhadap penelitian yang telah dilakukan sebelumnya. Dalam penelitian yang telah dilakukan oleh Sa'datur Rochmah yang berjudul "Pengembangan Bahasa Dalam Mengenal Huruf Melalui Media Kartu Huruf Pada Anak Kelompok B2 Raudhatul Athfal (RA) Al Amin II Salatiga", mendapat kesimpulan hasil penelitian bahwa penggunaan media kartu huruf dapat mengembangkan Bahasa dalam mengenal huruf pada anak kelompok B2 di RA Al Amin II Salatiga. Hal ini dibuktikan hasil pra-siklus sebelum penggunaan media kartu huruf $32 \%$ ( 3 anak) yang telah mulai mengenal huruf, sedangkan lainnya belum mengenal huruf. Siklus I menunjukan peningkatan yaitu $52 \%$ ( 3 anak) telah mencapai nilai KKP yang di tentukan dan siklus II kriteria ketuntasan Klasikal sebesar 99\% (15 anak). Dengan demikian perkembangan belajar siswa pada siklus I dan II mengalami Peningkatan 39\%, maka dari itu Penelitian Tindakan Kelas (PTK) dinyatakan berhasil (Rochmah, 2019, p. 1).

Sedangkan penelitian yang dilakukan oleh Siti Aenah yang berjudul "Peningkatan Kemampuan Mengenal Huruf Melalui Metode Permainan Kartu Huruf pada Kelompok A RA Nurul Ihsan Astana Japura Cirebon". Mendapat kesimpulan bahwa permainan kartu huruf dapat meningkatkan kemampuan mengenal huruf Kelompok A TRA Nurul Ihsan Astana Japura Cirebon. Hal ini dapat dibuktikan dengan meningkatnya kemampuan anak-anak dalam mengenal huruf. Kondisi pada pra siklus rata-rata mencapai $40 \%$, kemudian siklus I rata-rata meningkat menjadi $65 \%$ dan rata-rata siklus II mampu meningkat hingga $80 \%$. Peningkatan dari pra siklus ke siklus I sebesar 25\% dan peningkatan dari siklus I ke siklus II sebesar 15\% (Aenah, 2020, p. 1).

Peneliti menemukan masalah di RA Baiturrahman kelompok B, dikelompok B rata-rata berusia 5-6 tahun, terdapat beberapa anak-anak yang masih kesulitan untuk menyebutkan huruf a-z dengan jelas, pada saat berinteraksi dengan guru maupun dengan temannya anak masih susah untuk menybutkan kata yang akan 
diucapkannya. Adapun pembelajaran pada saat akan megenalkan 1 kata pada anak guru belum menggunakan media yang menarik yang dapat merangsang anak dalam perkembangan bahasa anak, guru hanya menuliskannya di papan tulis dan menunjuk kata yang tersedia di majalah anak. Seorang guru harus memiliki ketarampilan dalam membuat perencanaan serta keratif dalam membuat media untuk merangsang kemampuan berbicara anak, dengan menggunakan Kartu Huruf pembelajaran akan lebih efektif dan menarik.

\section{METODE PENELITIAN}

Metode penelitian dalam PTK merupakan uraian dari proses tindakan yang akan dikenakan kepada siswa/siswi secara detail. Metode penelitian dalam PTK terdapat langkah-langkah yang akan ditempuh peneliti dalam menggunakan tindakan kepada siswa/siswi. (Suyadi, 2010, p.89).

Metode yang digunakan dalam pengamatan ini yaitu metode jenis Penelitian Tindakan Kelas (PTK) dengan model Kemmis dan McTaggart, karena menurut peneliti, metode ini merupakan metode yang mudah untuk dilakukan. Menurut Zainal, model Kemmis dan McTaggart terdiri atas empat tahap, yaitu: (1) Perencanaan (planning) dan (2) pelaksanaan (Acting) (Zainal, 2014, p. 22).

Subjek atau sumber data yang diteliti oleh peneliti yaitu anak-anak kelompok B karena pada kelompok B inilah yang terdapat permasalahan yaitu kurangnya kemampuan bicara pada anak, maka peneliti tertarik unutk mengamatinya. Dalam pengamatan ini untuk mendapatkan yang valid, peneliti mengumpulkan data melalui pengamatan, wawancara, dan mengambil foto-foto saat pelaksanaan pengamatan. (Suyadi, 2011, p. 63).

\section{HASIL DAN PEMBAHASAN}

Berdasarkan pengamatan peneliti melakukan analisis prasiklus, kemampuan berbicara anak belum ada perkembangan, karena guru belum menyediakan media untuk merangsang perkembangan bahasa pada anak, pembelajaran yang dilakukan guru hanya mengandalkan papan tulis sehingga anak yang kemampuan bicaranya belum muncul masih saja tidak memperhatikan saat guru menunjuk salah satu huruf yang ada di papan tulis, adapun anak yang tidak jelas menyebutkan huruf yang ditunjuk oleh guru. Dalam hal ini guru memerlukan media yang mampu melatih kemampuan bicara anak bukan hanya mengandalakn papan tulis dan poster saja, sehingga terdapat beberapa anak yang masih kesulitan untuk menyebutkan huruf konsonan secara jelas.

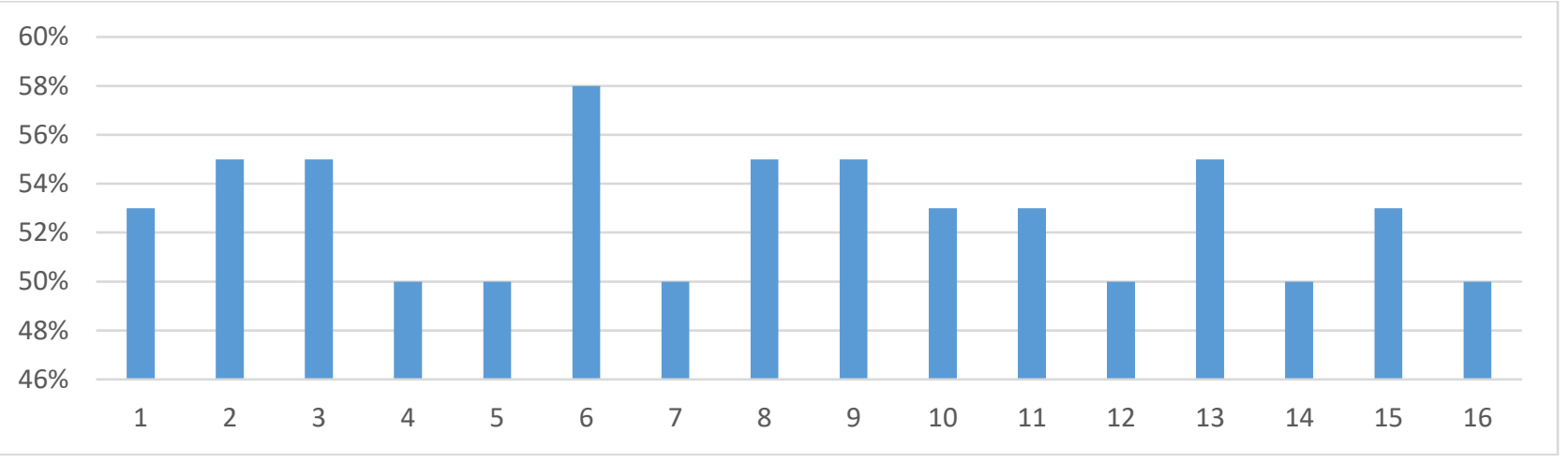

Gambar 1. Grafik prasiklus

Berdasarkan gambar grafik 1, dapat disimplkan bahwa kemampuan bicara pada anak kelompok B di RA Baiturrahman sebelum dilakukan tindakan kelas, terdapat banyak anak-anak yang belum dikatakan mencapai kriteria keberhasilan dalam kemampuan berbicara dengan presentase komulatif. Maka dari itu akan dilakukan tindakan melalui kartu huruf untuk mengatahui seberapa besar keberhasilan kemampuan berbicara saat dilakukan tindakan menggunkan media kartu huruf yaitu siklus 1.

Sebelum melakukan atau dilaksanakan penelitian tindakan kelas siklus 1, terdapat beberapa hal yang harus dilakukan guru yaitu menyiapkan Rencana Pelaksanaan Pembelajaran (RPPH), dan menyiapkan media berupa kartu huruf. Pelaksanaan Penerapan Media Kartu Huruf di RA Baiturrahman terdiri dari kegiatan awal, inti, istirhata, dan penutup. Kegiatan awal pembelajaran di RA Baiturrahman diawali dengan membaca Iqro yang didampingi oleh guru masing-masing kelas, setelah membaca Iqro anak melaksanakan baris-berbaris dihalaman sekolah, setelah anak berbaris dengan rapih membaca do'a ikrar bersama, membaca surat pendek, bernyanyi dan tepuk sebagai stimulasi kegiatan sebelum belajar.

Selanjutnya Kegiatan Pelaksanaan Media Kartu Huruf Kegiatan ini sering disebut kedalam kegiatan inti, sebelumnya guru menjelaskan tema yang akan dilaksanakan pada hari itu. Kemudian guru memberikan penjelasan bahwa hari ini ada kegiatan mengenal huruf a-z sambil menunjukan kartu huruf yang sudah disediakan, kemudian guru menjelaskan kartu huruf yang akan digunakan serta mencotohkan cara penggunaan media kartu huruf. Setelah anak paham guru memberikan tugas untuk menunjukan huruf $a-z$ dan mengucapkannya dengan jelas, selain huruf a-z terdapat kartu huruf yang terpisah yang akan menjadi sebuah 
kata sederhana sehingga anak bisa menyusunkan kartu menjadi satu kata yang bisa anak baca, contonya: ba ca menjadi baca.

Selanjutnya kegiatan istirahat. Sebelum anak-anak melaksanakan kegiatan istirahat guru menstimulasi denyan nyayian dan tepuk gembira. Setelah melakukan kegiatan bernyayi dan tepuk anak dipersilahkan untuk mencuci tangan terlebih dahulu, kemudian anak diperbolehkan menyantap makan yang dibawa dari rumah dan guru membebaskan anak-anak bermaian dihalaman sekolah namun tetap dalam pengawasan guru-guru dan wali murid.

Kegiatan terakhir yaitu kegaiatan penutup. Saat kegiatan penutup ini guru mengawali dengan bernyayi dan tepuk gembira. Pada kegiatan penutup ini guru mengevaluasi materi yang telah disampaikan, anak ditugaskan untuk menjawab pertanyaan-pertanyaan sederhana dari guru mengenai pembahasan yang telah disampaikan serta memberikan kesempatan untuk anak agar anak menceritakan kembali kegiatan yang sudah disampaikan oleh guru tadi. Mengulas isi kegiatan yang sudah disampaiikan agar dapat diketahui hasil belajar anak dan melatih daya ingat anak dalam mengingat materi yag telah disampaikan dan tidak lupa pula guru memberikan reward atau hadiah untuk anak yang sudah mengikuti kegiatan dari awal sampai akhir dengan baik.

Gambar 2 ada;ah hasil dokumentasi saat kegiatan penerapan permainan kartu huruf:
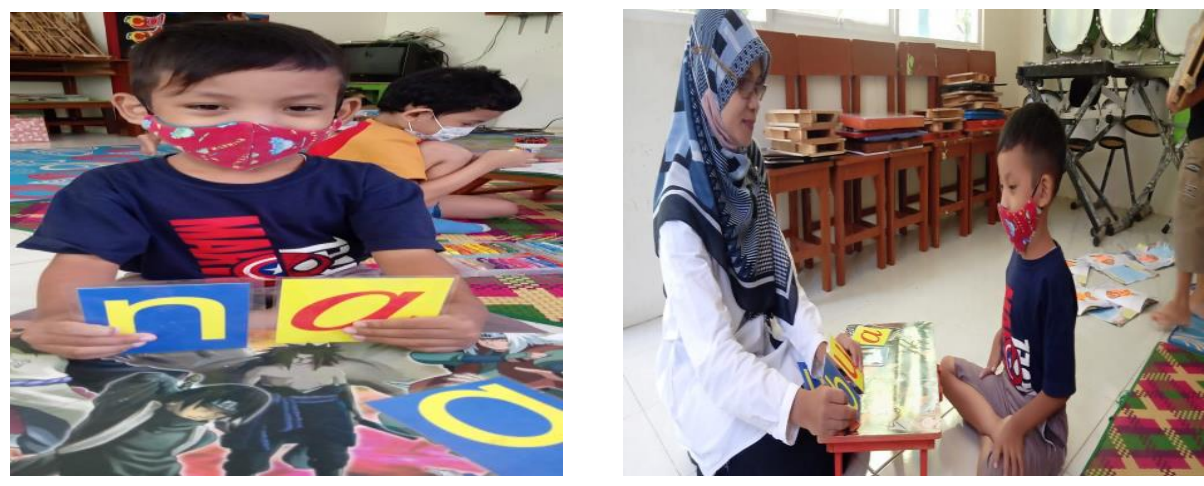

Gambar 2. Pelaksanaan Kegiatan Permainan Kartu Huruf Siklus 1

Hasil pengamatan yang dilakukan dalam pelaksanaan kegiatan media kartu huruf yang dilakukan selama 4 kali pertemuan. Penelitian siklus 1 mulai menarik presentase komulatif atau peningkatan dalam segi penilaian pada siklus 1 pertemuan 1-4 presentase komulatinya menarik hingga 70\% dari 100\%. Gambar 3 adalah grafik hasil perbandingan antara prasiklus dan siklus 1.

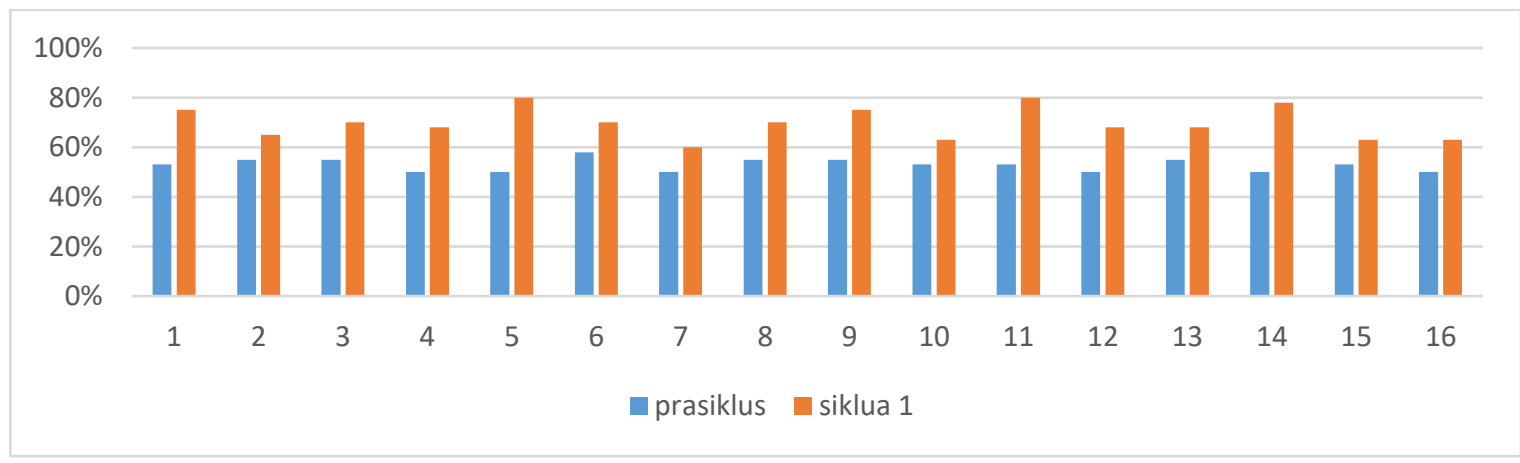

Gambar 3. Grafik perbandingan prasiklus dan siklus 1

Dari kajian pengamatan siklus 1 anak-anak tidak mau bergantian dengan teman saat menggunakan media tersebut. Bahkan terdapat anak yang belum bisa menyebutkan huruf dengan jelas dan menyusun kata dengan benar serta masih ada anak yang membaca kata dengan mengikuti gerak bibir gurunya. Untuk presentase komulatif pada prasiklus dan siklus 1 belum sesuai yang di inginkan peneliti yaitu presentase komulatif mencapai $80 \%$. Untuk itu peneliti akan menindak lanjuti dengan melakukan tindakan siklus 2.

Kegiatan pelaksanaan pada siklus 2 dilakukan sama dengan pelaksanaan sikuls 1 yaitu dengan melakukan penelitian selama 4 kali pertemuan yaitu sebelum dilaksanakan penelitian tindakan kelas siklus 2 , seperti biasa guru menyiapkan Rencana Pelaksanaan Pembelajaran (RPPH), dan menyiapkan media berupa kartu huruf.

Selanjutnya kegiatan awal. Kegiatan awal pembelajaran di RA Baiturrahman diawali dengan membaca Iqro yang didampingi oleh guru masing-masing kelas, setelah membaca Iqro anak melaksanakan baris-berbaris 
dihalaman sekolah, setelah anak berbaris dengan rapih membaca do'a ikrar bersama, membaca surat pendek, bernyanyi dan tepuk sebagai stimulasi kegiatan sebelum belajar.

Selanjutnya kegiatan inti, sebelumnya guru menjelaskan tema yang akan dilaksanakan pada hati itu. Lalu Guru menjelaskan bahwa hari ini ada kegiatan mengenal huruf a-z sambil menunjukan kartu huruf yang sudah disediakan, kemudian guru menjelaskan kartu huruf yang akan digunakan serta mencontohkan cara penggunaan media kartu huruf. Setelah anak paham guru memberikan tugas untuk menunjukan huruf $a-z$ dan mengucapkannya dengan jelas, selain huruf a-z terdapat kartu huruf yang terpisah yang akan menjadi sebuah kata sederhana sehingga anak bisa menyusunkan kartu menjadi satu kata yang bisa anak baca, contonya: ba ca menjadi baca.

Selanjutnya kegiatan istirahat Sebelum anak-anak melaksanakan kegiatan istirahat guru menstimulasi denyan nyayian dan tepuk gembira. Setelah melakukan kegiatan bernyayi dan tepuk anak dipersilahkan untuk mencuci tangan terlebih dahulu, kemudian anak diperbolehkan menyantap makan yang dibawa dari rumah dan guru membebaskan anak-anak bermaian dihalaman sekolah namun tetap dalam pengawasan guru-guru dan wali murid.

Kegiatan selanjutnya yaitu kegiatan penutup. Saat kegiatan penutup ini guru mengawali dengan bernyayi dan tepuk gembira. Pada kegiatan penutup ini guru mengevaluasi materi yang telah disampaikan, anak ditugaskan untuk menjawab pertanyaan-pertanyaan sederhana dari guru mengenai pembahasan yang telah disampaikan serta memberikan kesempatan untuk anak menceritakan kembali kegiatan yang sudah disampaikan oleh guru tadi. Mengulas isi kegiatan yang sudah disampaiikan agar dapat diketahui hasil belajar anak anak dan melatih daya ingat anak dalam mengingat materi yag telah disampaikan dan tidak lupa pula guru memberikan reward atau hadiah kepada anak yang sudah mengikuti kegiatan dari awal sampai akhir dengan baik. Gambar 4 merupakan dokumentasi saat kegiatan penerapan media kartu huruf pada siklus 2.

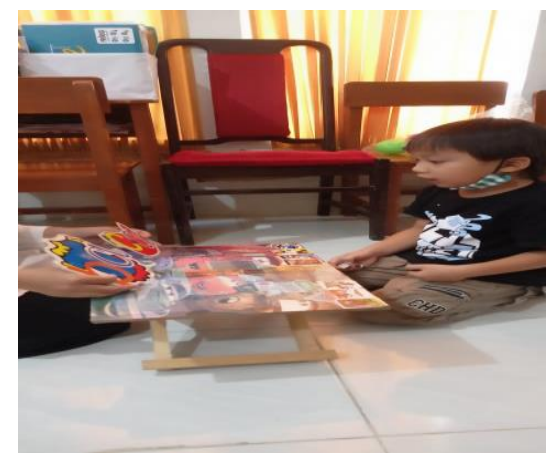

Gambar 4. Pelaksanaan Kegiatan Media Kartu Huruf Siklus 2

Hasil dari pengamatan pada pelaksanaan siklus 2 presentase komulatif atau peningkatan dalam segi penilaian pada siklus 2 pertemuan 1-4 presentase komulatinya sudah mengalami kenaikan hingga $86 \%$ dari 100 \%. Gambar 5 merupakan grafik hasil perbandingan antara prasiklus, siklus 1, dan siklus 2,

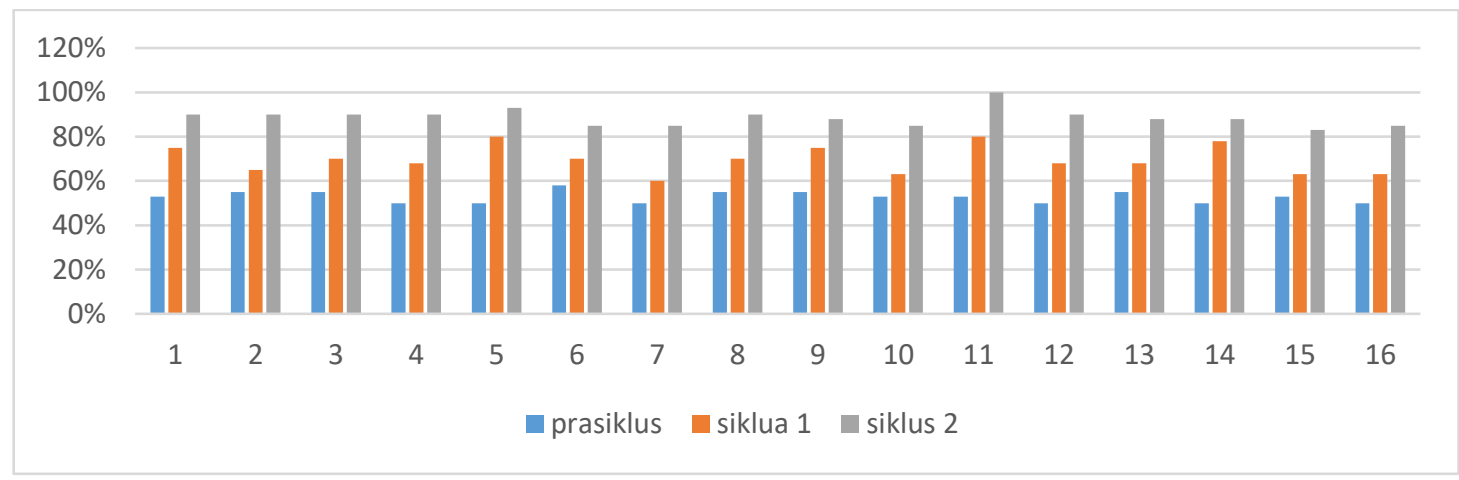

Gambar 5. Grafik perbandingan prasiklus, siklus 1 dan siklus 2

Dari kajian pengamatan siklus 2 peneliti menemukan perbedaan antara siklus 1 dan siklus 2 , bahwa pada pelaksanaan tindakan kelas siklus 2 , kegiatan pembelajaran sudah berjalan dengan baik, karena kondisi saat pembelajaran sangat kondusif dan anak-anak mampu membaca dengan baik maka dapat dikatakan bahwa kemampuan bahasa melalui media kartu huruf dapat dikatakan bahwa, melalui media kartu huruf dapat meningkatkan kemampuan bicara anak. 
Kegiatan pelaksanaan pada siklus 3 dilakukan sama dengan pelaksanaan sikuls 1,2 yaitu dengan melakukan penelitian selama 4 kali pertemuan yaitu sebelum dilaksanakan penelitian tindakan kelas siklus 3 , seperti biasa guru menyiapkan Rencana Pelaksanaan Pembelajaran (RPPH), dan menyiapkan media berupa kartu huruf.

Selanjutnya kegiatan awal. Kegiatan awal pembelajaran di RA Baiturrahman diawali dengan membaca Iqro yang didampingi oleh guru masing-masing kelas, setelah membaca lqro anak melaksanakan baris-berbaris dihalaman sekolah, setelah anak berbaris dengan rapih membaca do'a ikrar bersama, membaca surat pendek, bernyanyi dan tepuk sebagai stimulasi kegiatan sebelum belajar.

Selanjutnya kegiatan inti, sebelumnya guru menjelaskan tema yang akan dilaksanakan pada hati itu. Lalu Guru menjelaskan bahwa hari ini ada kegiatan mengenal huruf a-z sambil menunjukan kartu huruf yang sudah disediakan, kemudian guru menjelaskan kartu huruf yang akan digunakan serta mencontohkan cara penggunaan media kartu huruf. Setelah anak paham guru memberikan tugas untuk menunjukan huruf $a-z$ dan mengucapkannya dengan jelas, selain huruf a-z terdapat kartu huruf yang terpisah yang akan menjadi sebuah kata sederhana sehingga anak bisa menyusunkan kartu menjadi satu kata yang bisa anak baca, contonya: ba ca menjadi baca.

Selanjutnya kegiatan istirahat Sebelum anak-anak melaksanakan kegiatan istirahat guru menstimulasi denyan nyayian dan tepuk gembira. Setelah melakukan kegiatan bernyayi dan tepuk anak dipersilahkan untuk mencuci tangan terlebih dahulu, kemudian anak diperbolehkan menyantap makan yang dibawa dari rumah dan guru membebaskan anak-anak bermaian dihalaman sekolah namun tetap dalam pengawasan guru-guru dan wali murid.

Kegiatan selanjutnya yaitu kegiatan penutup. Saat kegiatan penutup ini guru mengawali dengan bernyayi dan tepuk gembira. Pada kegiatan penutup ini guru mengevaluasi materi yang telah disampaikan, anak ditugaskan untuk menjawab pertanyaan-pertanyaan sederhana dari guru mengenai pembahasan yang telah disampaikan serta memberikan kesempatan untuk anak menceritakan kembali kegiatan yang sudah disampaikan oleh guru tadi. Mengulas isi kegiatan yang sudah disampaiikan agar dapat diketahui hasil belajar anak anak dan melatih daya ingat anak dalam mengingat materi yag telah disampaikan dan tidak lupa pula guru memberikan reward atau hadiah kepada anak yang sudah mengikuti kegiatan dari awal sampai akhir dengan baik

Hasil dari pengamatan pada pelaksanaan siklus 3 presentase komulatif atau peningkatan dalam segi penilaian pada siklus 3 pertemuan 1-4 presentase komulatinya sudah mengalami kenaikan hingga $96 \%$ dari 100 \%. Gambar 6 grafik hasil perbandingan antara prasiklus, siklus 1, siklus 2, siklus 3.

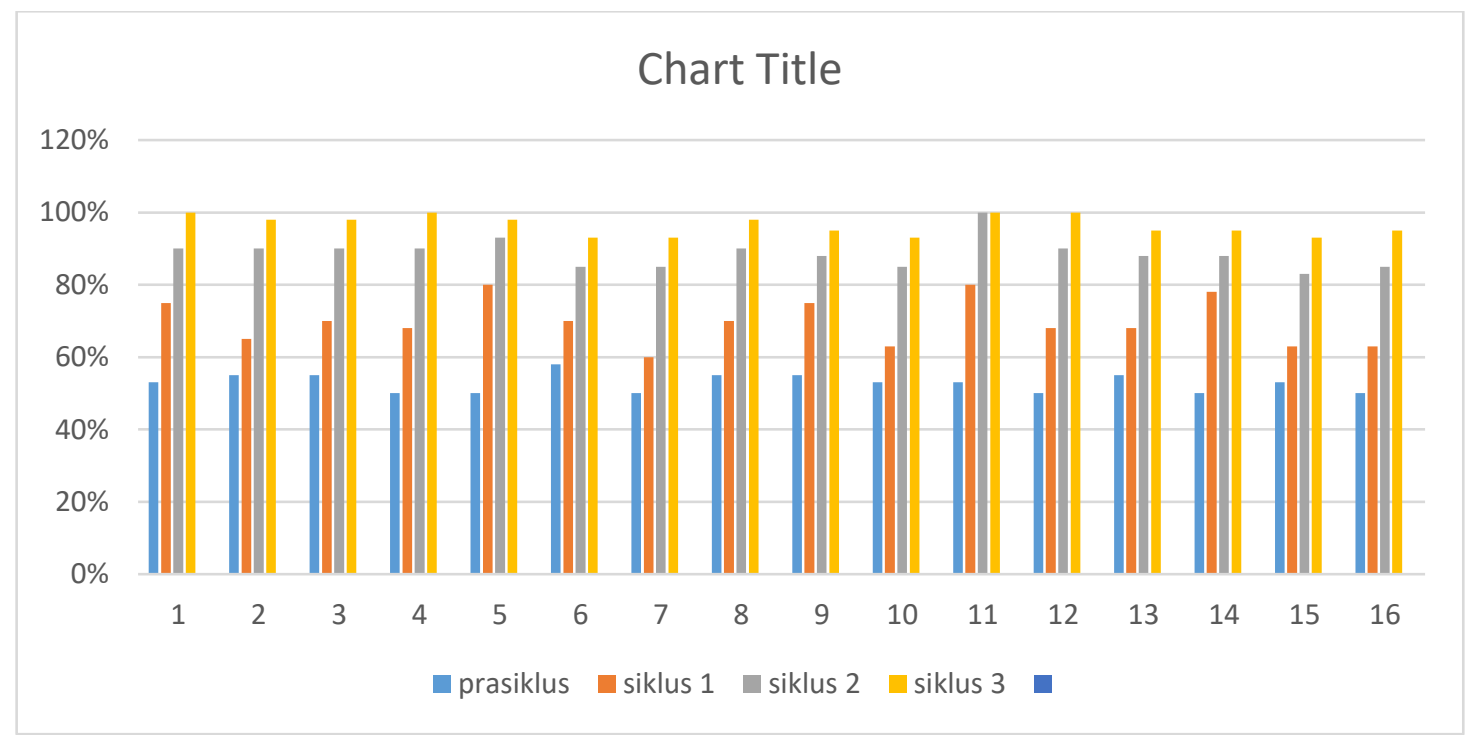

Gambar 6 grafik hasil perbandingan antara prasiklus, siklus 1, siklus 2, siklus 3

Kegiatan pelaksanaan pada siklus 4 dilakukan sama dengan pelaksanaan sikuls 1,2,3 yaitu dengan melakukan penelitian selama 4 kali pertemuan yaitu sebelum dilaksanakan penelitian tindakan kelas siklus 4 , seperti biasa guru menyiapkan Rencana Pelaksanaan Pembelajaran (RPPH), dan menyiapkan media berupa kartu huruf.

Selanjutnya kegiatan awal. Kegiatan awal pembelajaran di RA Baiturrahman diawali dengan membaca Iqro yang didampingi oleh guru masing-masing kelas, setelah membaca Iqro anak melaksanakan baris-berbaris dihalaman sekolah, setelah anak berbaris dengan rapih membaca do'a ikrar bersama, membaca surat pendek, bernyanyi dan tepuk sebagai stimulasi kegiatan sebelum belajar. 
Selanjutnya kegiatan inti, sebelumnya guru menjelaskan tema yang akan dilaksanakan pada hati itu. Lalu Guru menjelaskan bahwa hari ini ada kegiatan mengenal huruf a-z sambil menunjukan kartu huruf yang sudah disediakan, kemudian guru menjelaskan kartu huruf yang akan digunakan serta mencontohkan cara penggunaan media kartu huruf. Setelah anak paham guru memberikan tugas untuk menunjukan huruf a-z dan mengucapkannya dengan jelas, selain huruf a-z terdapat kartu huruf yang terpisah yang akan menjadi sebuah kata sederhana sehingga anak bisa menyusunkan kartu menjadi satu kata yang bisa anak baca, contonya: ba ca menjadi baca.

Selanjutnya kegiatan istirahat Sebelum anak-anak melaksanakan kegiatan istirahat guru menstimulasi denyan nyayian dan tepuk gembira. Setelah melakukan kegiatan bernyayi dan tepuk anak dipersilahkan untuk mencuci tangan terlebih dahulu, kemudian anak diperbolehkan menyantap makan yang dibawa dari rumah dan guru membebaskan anak-anak bermaian dihalaman sekolah namun tetap dalam pengawasan guru-guru dan wali murid.

Kegiatan selanjutnya yaitu kegiatan penutup. Saat kegiatan penutup ini guru mengawali dengan bernyayi dan tepuk gembira. Pada kegiatan penutup ini guru mengevaluasi materi yang telah disampaikan, anak ditugaskan untuk menjawab pertanyaan-pertanyaan sederhana dari guru mengenai pembahasan yang telah disampaikan serta memberikan kesempatan untuk anak menceritakan kembali kegiatan yang sudah disampaikan oleh guru tadi. Mengulas isi kegiatan yang sudah disampaiikan agar dapat diketahui hasil belajar anak anak dan melatih daya ingat anak dalam mengingat materi yag telah disampaikan dan tidak lupa pula guru memberikan reward atau hadiah kepada anak yang sudah mengikuti kegiatan dari awal sampai akhir dengan baik

Hasil dari pengamatan pada pelaksanaan siklus presentase komulatif atau peningkatan dalam segi penilaian pada siklus 3 pertemuan 1-4 presentase komulatinya sudah mengalami kenaikan hingga 99\% dari 100 \%. Gambar 6 grafik hasil perbandingan antara prasiklus, siklus 1, siklus 2, siklus 3, siklus 4 .

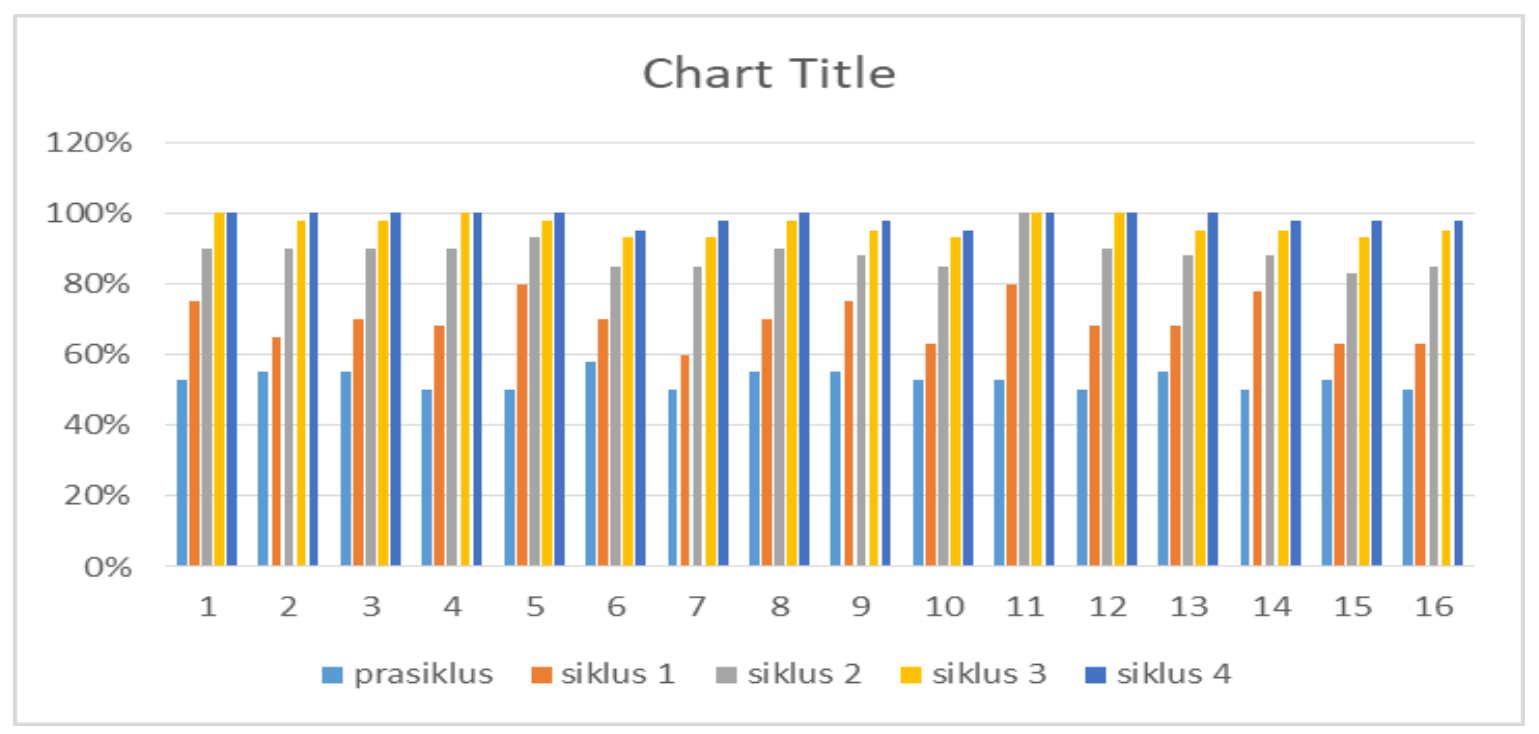

Gambar 6 grafik hasil perbandingan antara prasiklus, siklus 1, siklus 2, siklus 3, siklus 4

Dari kajian pengamatan siklus 4 peneliti menemukan perbedaan antara siklus 1 , siklus 2 , siklus 3 , dan siklus 4 bahwa pada pelaksanaan tindakan kelas siklus 4, kegiatan pembelajaran sudah berjalan dengan baik, karena kondisi saat pembelajaran sangat kondusif, anak-anak sangan antusias, anak-anak mampu membaca dengan baik, dan adanya kekreatifan guru pada saat kegiatan pembelajaran berlangsung sehingga, dapat dikatakan bahwa kemampuan bahasa melalui media kartu huruf dapat dikatakan bahwa, melalui media kartu huruf dapat meningkatkan kemampuan bicara anak.

\section{SIMPULAN}

Kemampuan bicara pada pada usia 4 sampai 5 tahun dapat ditingkatkan melalui media kartu huruf dan hal itu sangat efektif untuk dilakukan di RA Baiturrahman Bima Cirebon karena anak-anak bersemangat atau antusias saat melihat media yang digunakan oleh guru itu menarik yang penuh dengan warna-warna yang membat menarik anak.

\section{UCAPAN TERIMA KASIH}

Terima kasih untuk Allah SWT dan semua pihak yang sudah membantu peneilitian ini sehingga penelitian ini dapat terlaksana dengan baik. 


\section{DAFTAR PUSTAKA}

Aenah, S. (2020). Peningkatan Kemampuan Mengenal Huruf Melalui Metode Permainan Kartu Huruf pada Kelompok A RA Nurul Ihsan Astana Japura Cirebon. IAI Bunga Bangsa Cirebon.

Darsinah, Wusono Indarto, N. (2014). Meningkatkan Kemampuan Pengenalan Huruf Melalui Bermain Kartu Huruf Bergambar Pada Anak Usia 4-5 Tahun di KB Delima Indah Kecamatan Kerinci Kanan Kabupaten Siak. Universitas Riau.

Fauziddin, M., \& Fikriya, M. (2020). Mengenal Kosakata Bahasa Arab melalui Permainan Kartu Huruf Hijaiyah yang Dilengkapi Kosakata. Journal on Early Childhood Education Research (JOECHER), 1(2), 90-99. https://doi.org/10.37985/joecher.v1i2.13

Fitriyani, F., Sumantri, M. S., Supena, A., \& Info, A. (2019). Language development and social emotions in children with speech delay : case study of 9 year olds in elementary school. Jurnal IICET, 7(1), 23-29.

Irene Fitriana Wahyuni, Prana Dwija Iswara, C. S. (2017). Upaya Meningkatkan Kemampuan Berbicara Siswa Dalam Menceritakan Peristiwa Yang Dialami Menggunakan Metode Talking Stick Berbantuan Media Gambar Seri. Jurnal Pena Ilmiah, 2(1), 1541-1550. https://doi.org/10.17509/jpi.v2i1.10467

Istiarini, R. (2014). Peningkatan kemampuan berbicara melalui bermain balok. Jurnal Pendidikan Usia Dini, 8(1), 145-154.

Mahendrawani, A. (2019). Meningkatkan Kemampuan Berbahasa Melalui Permainan Kartu Kata Bergambar Pada Kelompok A TK Dharma Wanita Loyok. Jurnal Pendidikan Dan Ilmu Sosial, 1(20), 246-265.

Nurlaelah, N., \& Sakkir, G. (2020). Model Pembelajaran Respons Verbal dalam Kemampuan Berbicara. Edumaspul: Jurnal Pendidikan, 4(1), 113-122, 4(1), 113-122. https://ummaspul.ejournal.id/maspuljr/article/view/230

Pangastuti, R., \& Hanum, S. F. (2017). Pengenalan Abjad pada Anak Usia Dini Melalui Media Kartu Huruf. AlHikmah: Indonesian Journal of Early Childhood Islamic Education, 1(1), 51-66. https://doi.org/10.35896/ijecie.v1i1.4

Rochmah, S. (2019). Pengembangan Bahasa Dalam Mengenal Huruf Melalui Media Kartu Huruf Pada Anak Kelompok B2 Raudhatul Athfal (RA) Al Amin II Salatiga. IAIN Salatiga.

Septiyani, S., \& Kurniah, N. (2017). Pengaruh Media Big Book Terhadap Kemampuan Berbicara Pada Anak Usia Dini. Jurnal Potensia, 2, 47-56.

Sumantri, M., Sudana, D. N., \& Yoni Adnyana P, I. B. E. (2017). Penerapan Media Gambar Dan Kartu Huruf Untuk Meningkatkan Keterampilan Membaca Permulaan. International Journal of Elementary Education, 1(1), 1. https://doi.org/10.23887/ijee.v1i1.11433

Suyadi. (2010). Panduan Penelitian Tindakan Kelas. Alfabeta.

Suyadi. (2011). Penelitian Tindakan Kelas. Diva Press.

Tanjung, R. J. (2018). Penggunaan Media Kartu Huruf untuk Meningkatkan Kemampuan Anak dalam Mengenal Huruf Abjad pada Taman Kanak-Kanak Negeri Pembina I Kota Sabang. Jurnal Pendidikan Madrasah, 3(2), 321-322.

Zainal, A. dan. (2014). Penelitian Tindakan Kelas. CV. Yrama Widya. 